Marko Snoj

Inštitut za slovenski jezik Frana Ramovša ZRC SAZU

\title{
O prevzetih besedah, tujkah in izposojenkah
}

V članku terminološke narave avtor poskuša prevzete besede $\mathrm{z}$ eksaktnimi merili razmejiti na »izposojenke« in »tujke«. Razmejitev ni samo teoretičnega, temveč predvsem praktičnega pomena, saj je od ustrezne definicije termina »tujka« odvisno, kaj sodi in kaj ne sodi v dober slovar tujk.

The author of this terminologically oriented paper attempts to define in exact terms the distinction between "borrowings" and "foreignisms". The distinction is not merely theoretical, but of practical importance, as the definition determines what does and does not belong in a proper dictionary of foreignisms.

$0 \mathrm{~V}$ slovenski znanstveni, pa tudi $\mathrm{v}$ poljudni in drugi uporabni literaturi niti skozi zgodovino zadnjega stoletja niti danes ni enotnega mnenja, kaj je to »tujka«, kaj "prevzeta beseda in kaj »izposojenka«.

1 Začnimo na sredi, kjer je najmehkeje: vsi se bomo strinjali, da je za nas prevzeta vsaka beseda, ki ni nastala $\mathrm{v}$ kontinuiranem razvoju slovenščine, nekoč od davne pradavnine do danes, ki torej ni motivirana s slovenskimi (oz. slovenščini predhodnimi) besedotvornimi sredstvi. Za besedo račún ugotavljamo, da je prevzeta, ker ni nastala $\mathrm{v}$ slovenskem jezikovnem kontinuumu, ampak je $\mathrm{v}$ srednjem veku prevzeta iz neke romanske predloge, ki se je razvila iz lat. tožilnika ratiōnem, spadajočega $\mathrm{k}$ imenovalniku ratiō 'račun, obračun' in 'razum'. Beseda je motivirana $\mathrm{v}$ italščini, saj gre za tvorjenko iz pridevnika, ki se ohranja v lat. ratus 'preračunan, veljaven, določen, potrjen, odmerjen', ta pa je s praindoevropskimi besedotvornimi sredstvi tvorjen iz glagola, ki se ohranja v lat. rēer $\bar{l}$ 'računati, misliti'. Ta glagol pomensko še najbolj ustreza praslovanskemu *čisti, *čbto, iz katerega imamo danes šté$t i$. Beseda račún oz. lat. predhodnica romanske predloge je torej motivirana $\mathrm{v}$ jezikovnem kontinuumu latinščine, njen prvotni pomen je *'računanje', tj. *'razmišljanje o količinah, o številkah'.

1.1 Nasprotno pa beseda računálnik ni prevzeta, saj je motivirana v slovenščini. S slovenskimi besedotvornimi sredstvi je tvorjena iz glagola račúnati (kakor je npr. kuhálnik prek imena orodja kuhálo tvorjen iz kúhati), ta pa je prav tako s slovenskimi sredstvi tvorjen iz prevzete, pa vendar že slovenske besede račún.

2.1 Besedno zvezo na posodo vzeti je za ljudske izposojenke uporabljal že Fran Erjavec, npr. v Letopisu Matice slovenske za leto 1879, piše na strani 186: 'Beseda sak je uže davno v slovanska narečja vzeta na pósodo.' Zveza v tej rabi je seveda kalk po nemškem glagolu entlehnen, slovenska tvorjenka izposojenka pa poenobesedena (s tujko univerbizirana) iz zveze izposojena beseda, ki je kalk nemške zloženke Lehnwort. Uporaba korenskega morfema s pomenom 'izposoditi si' $\mathrm{v}$ tej zvezi se nekaterim ni zdela primerna, češ da izposoja pomeni le začasen prevzem $\mathrm{v}$

\footnotetext{
${ }^{1}$ Walde, Hofmann 1938-56: II, 418.
} 
last ali posest $\mathrm{z}$ namenom, da se ista ali enakovredna stvar vrne prvotnemu lastni$\mathrm{ku}$, takega namena pa pri prevzemu besed ni. Zato je Jože Toporišič v drugi polovici 20. stoletja kot sinonim terminu izposoditi si uvedel termin prevzeti, ki je prav tako kalk, tokrat nemške besede übernehmen. Od tedaj je "prevzeta beseda « krovni izraz, ki obsega vse besede nekega jezikovnega kontinuuma, ki so vanj prišle od zunaj, iz kontinuuma katerega koli drugega jezika.

2.2 Besede tujega izvora se že pri Antonu Brezniku delijo na izposojenke in tujke. Izposojenke so zanj 'besede, ki si jih je izposodil preprosti narod, občujoč s sosedi, ter jih vzel za svoje, ko jim je tuje zveneče glasove spremenil v bližnje domače'. Tujke so za Breznika 'vse one besede, ki jih rabimo navadno v znanstvu, v tehniki in sploh $v$ omikanem svetu ter jih pozna le tisti, ki je zvedel zanje po izobrazbi, po kakršni koli že'.2

2.3 Breznikova delitev prevzetih besed na izposojenke in tujke vsekakor ustreza, njegovi definiciji pa le deloma. Pri izposojenkah Breznikovo definicijo deloma preseže Ramovševa formulacija, uporabljena $\mathrm{v}$ napotkih za izdelavo Etimološkega slovarja slovenskega jezika, kjer pravi, da naj bi slovar vseboval tudi vse izvorno tuje besede, ki jih je živi jezik po svoje prekvasil. Vendar tudi to še ni absolutno merilo, saj imamo tudi ljudske izposojenke, ki se v slovenščini še danes glasijo tako kot $\mathrm{v}$ izvirnem jeziku, npr. olíva iz it. oliva ali púf iz furl. puf. Izposojenka je točneje izraženo 'beseda, ki si jo je preprosto ljudstvo izposodilo iz enega sosednjih jezikov.' To pomeni, da je izposojenka praviloma beseda, ki je iz enega sosednjih narečij (beneške italijanščine, tergestinščine, furlanščine, bavarske, tirolske nemščine, zahodne madžarščine, kajkavske ali čakavske hrvaščine, romščine) prešla $\mathrm{v}$ sosednje slovensko narečje in od tod eventualno $\mathrm{v}$ druga slovenska narečja ter $\mathrm{v}$ knjižni jezik. Slovenščina je tako besedo po svoje prekvasila le po potrebi, in sicer:

1. Če je tujejezična predloga vsebovala slovenščini tuj glas ali glasovno skupino, najpogosteje podvojitev, npr. bákla iz srvnem. vackel (slovenščina tistega časa ni imela niti glasu $f$ niti spirantičnega $b$, ki se je $\mathrm{v}$ srvnem. zapisoval $\mathrm{z} v$ ), cimet iz star. nem. Zimmet, danes Zimt.

2. Če je bila potrebna morfološke prilagoditve, npr. pônev iz stvnem. pfanna, cóprati iz bavarsko srvnem. zoupern, kar ustreza širše srvnem. zoubern, frájla iz bav. nem. Frailein, kar ustreza knjiž. Fräulein, lájbič iz bav. nem. Leiblein 'telovnik'.

3. Iz drugih, manj opredeljivih razlogov, npr. marajón prek majarón iz furl. majaron. Do nepričakovanega premeta soglasnikov je tu $\mathrm{v}$ nekaterih slovenskih narečjih prišlo zato, ker prevzete besede $\mathrm{v}$ jeziku prejemniku niso motivirane. Del našega ljudstva si je besedo preprosto slabo zapomnil in iz prvotnega majaróna "po pomoti« naredil marajón.

4. Dodati je treba, da je marsikatera sprememba v slovenščini le navidezna, saj ne smemo izhajati iz sosednjega knjižnega jezika, temveč iz narečja. Če rečemo, da je pávola iz nem. Baumwolle, je to le delno res in nikakor ne točno. Pávola je iz narečne avstrijsko-bavarske besede pa(um)wolle 'bombaž', ki ustreza nemški knjižni Baumwolle. Tudi pònk ni iz nemške besede Bank, temveč iz bavarske ponk, ki se je po bavarskonemških zakonih razvila iz srvnem. bank 'klop, miza'.

3 Pri tujkah se tuji glasovi zamenjajo $\mathrm{z}$ našimi približki, beseda pa prilagodi našemu morfološkemu sistemu. $\mathrm{V}$ besedi brinéta, ki je iz frc. brunette, se je tako tu-

\footnotetext{
${ }^{2}$ Breznik 1906: 149, ki namesto danes ustaljenega krovnega izraza »prevzeta beseda« le bežno uporabi izraz »tuja beseda«.
} 
jejezični glas $\ddot{u}$ zamenjal $\mathrm{z}$ našim približkom $i$. Poleg tega se je beseda zaradi naravnega spola poimenovanega uvrstila $\mathrm{v}$ produktivno žensko sklanjatev. Tujka se $\mathrm{v}$ slovenščini prilagodi le $\mathrm{v}$ zgoraj navedenih točkah 1) in 2), tj. tujejezični glasovi, ki jih slovenščina ne pozna, se nadomestijo $\mathrm{z}$ našimi približki, in tujka se rada prej ali slej vklopi v naš morfološki sistem. Nepričakovanih glasovnih razvojev tipa marajón pri tujkah ni in tudi narečnih posebnosti tujega jezika tujke praviloma ne izražajo. Breznik ima prav, ko trdi, da se tujke navadno uporabljajo v znanosti, v tehniki, v omikanem svetu, da so posledica izobrazbe, vendar to ni zaprta definicija, zlasti pa ne zadošča danes, ko nekatere tujke, kot npr. ávto, sodijo med prvih deset besed, ki se jih nauči otrok še $v$ plenicah. Tujke je zato bolje definirati kot 'besede, ki so jih slovenski izobraženci vpeljali v slovenski knjižni jezik iz tujih knjižnih jezikov'. Nekaj so jih prinesli že protestanti v 16. stoletju, npr. cédra, elemènt, velika večina pa je prevzeta šele $v$ drugi polovici 19. stoletja in kasneje. Zaradi te večine po občutku sodimo, da so tujke pri nas mlade besede in s tem delamo krivico onim, ki imajo pri nas knjižno tradicijo že tri ali štiri stoletja. Pri Janezu Svetokriškem npr. beremo S. Joannes Apoftel njega fa shilo, ali puls prime. Tujka pulz je torej pri nas stara že vsaj 300 let.

3.1 Osnovna razlika med izposojenko in tujko je torej ta, da je izposojenko preprosto ljudstvo vpeljalo iz sosednjega narečja tujega jezika v svoje narečje, tujka pa je prevzeta beseda, ki jo je v slovenski knjižni jezik iz tujega knjižnega jezika vpeljal izobraženec. Povedano še krajše: izposojenka je ljudska, tujka pa knjižna prevzeta beseda. ${ }^{3}$

3.1.1 Izhodiščna pozicija izposojenke je govorjeni jezik, praviloma narečje, izhodiščna pozicija tujke pa napisani, praviloma knjižni, pogosto strokovni jezik. ${ }^{4}$ Iz izhodiščne pozicije si je prevzeta beseda lahko ali pa ne utrla pot tudi v druge zvrsti: majarón je kot prvotna izposojenka našla mesto tudi $\mathrm{v}$ knjižnem jeziku, ávto pa kot prvotna tujka tudi $\mathrm{v}$ pogovornem jeziku in narečjih. Motiv za prevzem je pri izposojenkah in tujkah enak. Preprosti človek ali izobraženec je besedo, ki jo je slišal oz. videl zapisano $\mathrm{v}$ tujem jeziku, uporabil $\mathrm{v}$ svojem jeziku, ker je $\mathrm{z}$ njo hotel poimenovati stvar, pojem ali dejanje, za katerega $\mathrm{v}$ svojem besednem zakladu ni našel ustreznega poimenovanja; bodisi da za ustrezno besedo v svojem jeziku ni vedel, bodisi da je dejansko ni bilo.

\footnotetext{
${ }^{3}$ Poznamo primere, ko imamo iz istega izhodišča izposojenko in tujko, npr. iz frc. reine-claude si je preprosto ljudstvo prek avstr. nem. Ringlotte izposodilo ringló (nekdo je ob tem po hiperfrancoski maniri izpustil končni $-t$, tako kot ga preprosto ljudstvo danes izpušča $\mathrm{v}$ pomfrí, čeprav ga Francozi v svoji besedni zvezi pommes frittes še kako jasno izgovarjajo), učeni pomologi pa renklóda neposredno iz francoščine.

${ }^{4}$ Naša tujka se torej le delno pokriva s tem, kar je Italijanom voce dotta, Francozom mot savant, mnogo bliže je temu, čemur pravijo Nemci Fremdwort. Razlog je predvsem v tem, da so Italijani in Francozi lahko učene neologizme v večji meri tvorili iz avtohtonih morfemov z lastnimi ali vsaj latinskimi besedotvornimi sredstvi, ki spadajo v njihov jezikovni kontinuum, da so se te besede potem kot internacionalizmi širile $\mathrm{v}$ druge ne (bližnje) sorodne jezike, medtem ko Nemci, Slovani in drugi vzhodnjaki nismo imeli take možnosti. Naši neologizmi praviloma niso migrirali na Zahod. Podobno kot $\mathrm{v}$ romanskem svetu je tudi $\mathrm{v}$ novi grščini, ki ima veliko neologizmov,

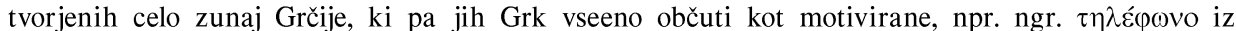
stgr. $\tau \tilde{\eta} \lambda \varepsilon$ 'daleč, v daljavi' + $\varphi \omega v \eta ́$ 'glas, zvok'. Beseda je bila za potrebe poimenovanja nekega akustičnega aparata tvorjena leta $1834 \mathrm{v}$ francoščini kot téléphone. $\mathrm{V}$ današnjem pomenu se najprej pojavi v angleščini leta 1876, ko je Alexander Graham Bell z njo poimenoval svoj izum.
} 
3.2 Tako je tujke sicer bolj na intuitivni kot na eksplicitni ravni pojmoval France Verbinc v svojem znamenitem Slovarju tujk. V tem delu le izjemoma najdemo geselske iztočnice, ki ne ustrezajo podani definiciji, in le izjemoma pogrešamo kako tujko, ki je bila ob izidu leta 1968 v vsaj malo širši rabi.

3.3 Zakaj je pravzaprav treba tako na široko pisati o nečem, kar je vsaj pri Brezniku že dobro zastavljeno, kar je pri Verbincu že uporabljeno v praksi in kar bi danes potrebovalo le še manjših popravkov? Razlog je $\mathrm{v}$ tem, da sta slovenska jezikovnoteoretična misel $\mathrm{v}$ zadnjih desetletjih, $\mathrm{v}$ najnovejšem času pa $\mathrm{v}$ še večji meri slovaropisna praksa, začeli tujko pojmovati drugače, po mojem uvidu manj ustrezno. V Enciklopediji slovenskega jezika Toporišič piše, da je tujka »1. prevzeta beseda, ki ni povsem prilagojena slovenščini, npr. jazz (kot sposojenka džez)«/.../»2. v starejšem pojmovanju iz zahodnoevropskih ali klasičnih jezikov prevzeta beseda, npr. avto, kros /.../ ${ }^{5}$ Prva Toporišičeva definicija je dragocena zato, ker pri tujkah izpostavlja pisani jezik. Vendar pa se ni mogoče strinjati z nazorom, da bi bila džéz druga beseda kot jazz, pač pa sta to samo alografa iste besede, kot sta alografa npr. tríkrat in 3-krat. Beseda je namreč sestavljena in morfemov, morfemi pa iz fonemov in vse to so pojavi psihičnega sveta. Kakor je fonem predstava o glasu, ki ima pomenskorazlikovalno vrednost, tako je tudi beseda, ki jo v končni konsekvenci sestavljajo fonemi in ne glasovi ali celo črke, zgolj psihična kategorija. Podobno kot se fonem lahko realizira $\mathrm{v}$ obliki glasu ali črke, tudi besedo lahko realiziramo na več načinov, lahko jo izgovorimo, napišemo, nakažemo ali nanjo samo pomislimo. Dalje so po prvi definiciji tujke le citatno pisane besede, po drugi so to vse iz zahodnoevropskih in klasičnih jezikov prevzete besede. Skupna slaba stran obeh definicij je, da postavita $\mathrm{v}$ isti koš učene besede tipa névma, kloramfenikól, ki so prilagojene našemu jeziku (nevmo pišemo $\mathrm{z} v$, kloramfenikol pa $\mathrm{s} k$ in $f$ ) in ljudske izposojenke tipa málha, híša, žlémprga, fájmošter, ki so prevzete iz zahodnoevropskih jezikov.

3.4 Na takih teoretičnih izhodiščih ni mogoče napisati slovarja tujk, saj bi bil upoštevaje prvo definicijo neuporaben zato, ker bi vseboval premalo besed, namreč le citatno pisane tipa jazz, judo, knockout, ketchup, manjkale pa bi podomačeno pisane, npr. demokracíja, névma, kloramfenikól; upoštevaje drugoomenjeno pa bi moral vsebovati preveč besed, ki spadajo le v splošne razlagalne slovarje, npr. híša, fànt, púnca, še vedno pa ne bi vseboval besed, kot so černozjóm, dúma ali hazéna. Zato sestavljalci Velikega slovarja tujk na str. XII, kjer sicer priznavajo, da slovar vsebuje tudi izposojenke, tujko pojmujejo kot besedo, »ki je bila v drugi polovici 19. stoletja ali v 20. stoletju izposojena v slovenski jezik (in še druge jezike) iz tujega knjižnega, lahko tudi že mrtvega jezika, ter se uporablja le $\mathrm{v}$ knjižnem jeziku in temu najbližjih jezikovnih ravninah. ${ }^{6}$ To teoretično izhodišče, dopolnjeno $\mathrm{z}$ na isti strani Velikega slovarja tujk natisnjenimi nadaljnjimi merili za uvrstitev v slovar, za hudo silo še ustreza, čeprav ignorira dejstvo, da so nekatere tujke, kot npr. cédra, elemènt, študènt, uvedene že v 16. stoletju, vendar se praksa od njega na naslednjih

\footnotetext{
${ }^{5}$ Toporišič 1992: 334. Enako stališče navaja tudi v Toporišič 2000: 131: »Danes nam izposojenke pomenijo tiste prevzete besede, ki so se docela prilagodile slovenskemu jeziku v izgovoru, pisa vi, pregibanju, skladnji, tvorjenju novih besed ipd. Takih prevzetih besed je ogromna večina. (Tako jih je pojmoval že Škrabec.) Tujke pa imenujemo tiste prevzete besede, ki se slovenščini niso prilagodile popolnoma, temveč le $\mathrm{v}$ večji ali manjši meri. Večinoma so nepopolno prilagojene zlasti $\mathrm{v}$ pisavi, redko v izgovoru in pregibanju (prim. npr. pisne tujke jazz, piano, sociologija).«

${ }^{6}$ Definicija je skoraj dobesedno povzeta po Snoj 1997: III.
} 
1300 straneh preveč oddalji. Moj namen nikakor ni kritiziranje tega, pogojno sicer uporabnega slovarja (čeprav je to verjetno nižek slovenskega slovaropisja), temveč le spotoma opozoriti na nekatere besede, ki resnično ne sodijo v slovar tujk, saj so domačega izvora, npr. lázar (ki je iz sloven. láziti), hržica 'vrsta mušice' (pravilen naglas je po SP 2001 hržíca, beseda je tvorjena iz sloven. hrga 'grča'), pretín (tvorjeno iz pretíniti 'pregraditi', to pa iz tìn 'pregradna stena', kar je sicer stara, že praslovanska izposojenka iz germanščine) ali lúna, ki ni iz latinščine, ampak je kakor hrv., srb. lúna in rus. luná z latinsko besedo le sorodna in po vseh fonetičnih pravilih razvita iz istega indoevropskega izhodišča. Seznam domačih besed, ki jih kot tujke navaja Veliki slovar tujk, je mogoče še znantno podaljšati. Od omenjenih primerov je Verbinc v svoj slovar uvrstil le luno, kar pa mu ne gre zameriti, saj se je zanašal na podobnost slovenske besede $\mathrm{z}$ latinsko, pri tem pa $\mathrm{v}$ nasprotju s sestavljalci Velikega slovarja tujk $\mathrm{v}$ svojem času ni imel na voljo nobenega slovenskega etimološkega slovarja, $\mathrm{v}$ katerem bi domnevo o tujem izvoru besede lúna lahko potrdil ali ovrgel.

3.5 Kaj naj bi torej vseboval zares uporaben in korektno napisan slovar tujk, če hočemo, da bi njegova vsebina ustrezala naslovu? Skladno z definicijo tujke bi moral vsebovati le tiste besede, ki so jih slovenski izobraženci od 16. stoletja dalje vnesli v slovenski knjižni jezik iz drugih tujih jezikov in ki se še danes uporabljajo ali bi se lahko uporabljale, in sicer ne glede na to, ali se pišejo citatno (jazz) ali podomačeno (džéz). Poleg tega bi bilo v slovar tujk upravičeno uvrstiti tudi tiste slovenske izpeljanke iz tujk, ki so dejansko žive, npr. jazzovski oz. džézovski. Tak slovar tujk se na Slovenskem pripravlja že vrsto let in pričakovati je, da bo v doglednem času zagledal luč sveta.

3.6 Slovaropisna praksa lahko šepa tudi, če so teoretična izhodišča še kar dobra. V praksi se namreč vsaka teoretična razpoka spremeni $\mathrm{v}$ težko prehodno brezno. Razlogov za to je sicer več, vendar bi se v članku rad omejil le na tri delčke enega. To so mejni primeri.

3.6.1 Tujka $\mathrm{v}$ osnovnem pomenu je beseda, ki je $\mathrm{z}$ najnujnejšimi prilagoditvami prevzeta v slovenski pisani jezik, npr. džéz, džezíst. Ali naj torej dober slovar tujk vsebuje tudi slovenske tvorjenke, kot sta džézovski in džezistka? Verjetno da. Ali naj vsebuje tudi džézovstvo, džézovstven in džézovstvenski, česar SP 2001 sicer nima, si je pa mogoče predstavljati, da bi izraze lahko skoval in uporabil kak glasbeni kritik. Domnevam, da te tri besede ne bi več sodile v slovar tujk. Verbinc se ustavi že prej, saj slovenske tvorjenke tipa jazzovski navaja le izjemoma (na jazzista je pozabil, feminativov pa sploh nima). Mejo med še sprejemljivim in že nepotrebnim bo danes verjetno morala postaviti pogostnost rabe. Gotovo pa so v slovarju tujk nepotrebne predvidljive manjšalnice tipa jáguarček, pirománčica.

3.6.1.1 Po zdravi pameti bi sodili, da nekatere domače priponske tvorjenke še nekako sodijo v dober slovar tujk, predponske pa že komaj: ob nedovršniku diskutírati bi bilo morda $\mathrm{v}$ istem geselskem članku še smiselno omeniti dovršnik prediskutírati. Ne zdi pa se smiselno teh besed postavljati na svoja abecedna mesta, vsaj za odrasle potrebe ne, verjetno pa bi to imelo smisel za šolsko rabo, to pa pomeni uvrstitev le v tanjši, šolski slovar tujk, v katerem bi moralo manjkati skoraj vse, kar presega srednješolsko učenost. Ko se najstnik sreča $\mathrm{z}$ besedo prediskutírati, še ni rečeno, da že pozna tudi simpleks, zato bo glagol morda iskal na svojem abecednem mestu. Večja potreba po uvrstitvi $v$ dober slovar tujk se kaže le $\mathrm{v}$ primerih, $\mathrm{v}$ kate- 
rih domača predpona nima samo vidske funkcije, temveč tudi pomensko, npr. razformírati, preformírati, preformulírati. Nemci so se v slovarjih tujk izognili tudi takim besedam. Dudnov Das große Fremdwörterbuch tako nima glagola umformulieren, ima ga pa splošni Dudnov Deutsches Universalwörterbuch.

3.6.1.2 Še manj možnosti za uvrstitev v slovar tujk imajo hibridne sestavljenke tipa nèkonvencionálen, prótitánkovski, čeprav tudi ni izključeno, da bi jih kdo utegnil iskati. Ker bi obravnava vseh takih besed knjigo odebelila do nerazumne mere, bi se jih spet zdelo pametno v omejenem obsegu uvrstiti le v šolski slovar tujk.

3.6.1.3 Še najbolj sporne pa so sicer redke hibridne zloženke, besede, pri katerih je en koren tujek, drugi pa domačega izvora, še zlasti, če je domači koren kalkiran, npr. delohólik po agl. workaholic. Eksaktnega odgovora na vprašanje, ali take besede sodijo v splošni slovar tujk, ni. Ker ti primeri ne bi bistveno odebelili slovarja in ker tudi džezístka ni tujka v strogem pomenu besede, ampak njena potomka, ker smo torej strogo načelo že prekršili, ga lahko tudi v teh primerih.

3.6.2 Na drugem mestu je treba omeniti slengovske besede, ki jih uvaja predvsem mlajša, najstniška generacija, ko pa ta zraste, se razširi tudi med govorci srednjih let, npr. kúl 'dobro', šit 'nekaj slabega', džánki 'zasvojenec s heroinom'. Ker so te besede prevzete iz angleščine, jih ne moremo imeti za klasične izposojenke; ker njihovo izhodišče ni v knjižnem ali vsaj pisanem jeziku, pa ne za tujke. Kljub zadržku so te besede vendarle izposojenke, saj si jih je izposodila odraščajoča mladina, torej še ne dokončno izobraženi del ljudstva $\mathrm{v}$ sleng, to pa je govorica, ki se praviloma ne zapisuje in ki je po zvrsti mnogo bližje narečju kot knjižnemu jeziku. Izposoja se sicer ni zgodila na mejnem ali jezikovno mešanem področju, kot je to navadno pri klasičnih izposojenkah, temveč doma pred televizorjem ali v kaki poletni šoli na Britanskem. Ker nas angleščina obkroža ne samo v elektronskih medijih, ker nam poznavanje tega jezika zadošča ne samo na Britanskem otočju, ZDA in Avstraliji, ampak skorajda že v Trstu in Celovcu, je ta jezik (oziroma kar je iz njega nastalo) postal tako rekoč sosed slovenskemu, torej eden tistih jezikov, iz katerih si besede izposoja slovensko ljudstvo. Ta vrsta besed zato ne sodi v slovar tujk, in sicer ne glede na to, kako jih pišemo, džánki (priporočljivo), junky/junkie (citatno) ali danki, kot beremo v grafitu na ljubljanski frančiškanski cerkvi. Treba bi jih bilo zbrati in slovarsko obdelati v slovarju slenga, ki ga Slovenci še nekaj časa očitno žal ne bomo imeli.

3.6.3 Tretja vrsta mejnih primerov so tiste besede, ki so jih slovenski izobraženci v drugi polovici 19. stoletja vpeljali v slovenski knjižni jezik iz drugih slovanskih jezikov, v glavnem $\mathrm{z}$ namenom izpodriniti »neprimerne, grde popačenke «, ljudske izposojenke iz nemščine, redkeje italijanščine ali furlanščine. Tako je ljudskega fájmoštra (pa tudi pôpa in plebána) nadomestil hrvaški žúpnik, namesto ljudske izposojenke gás imamo danes češki plín (ki je prevzet iz poljščine, tam pa pomeni 'tekočina'), ljudsko fasádo hoče izpodriniti hrvaško pročélje, ljudsko vížo je nadomestil hrvaški načín (domača beseda način v 17. stoletju pri Alasii pomeni 'udobje'), ljudsko žájfo je nadomestilo rusko mílo. Takih in podobnih primerov je na stotine.

\footnotetext{
${ }^{7}$ Slovenščina je slovanski jezik, ki se je od 6. stoletja dalje razvijal na (približno) današnjem ozemlju bolj ali manj samostojno od jezikov ostalih Slovanov, zaradi zemljepisne lege in srednjeveških migracij pa pod močnim bavarskim in manj močnim romanskim vplivom. Slovenskost slovenščine ni samo v njeni slovanskosti, temveč v posebnem razvoju slovanščine na naših tleh. Ena
} 
Danes bi bilo nesmiselno hudovati se nad temi purističnimi zamenjavami, ${ }^{8}$ saj so se te prvotne tujke $\mathrm{v}$ več kot sto letih šolske vzgoje tako prijele, da jih ne občutimo več kot tuje. Postale so del našega omikanega jezika, ki mu kljub manj ali sploh nejasni motiviranosti podzavestno priznavamo slovenskost. To pa je zadosten razlog, da jih ne uvrstimo $\mathrm{v}$ slovar tujk, temveč $\mathrm{v}$ bolj znanstveno zasnovan projekt, o katerem se danes še ne razmišlja, ki bi z zgodovinskega in etimološkega stališča obravnaval vse iz drugih slovanskih jezikov prevzete, bolj ali manj prilagojene besede.

3.6.3.1 Seveda to ne pomeni, da vse iz drugih slovanskih jezikov prevzete besede ne spadajo $\mathrm{v}$ dober slovar tujk. Izključene so le tiste, ki so prek pisanega jezika prešle v splošno omikano rabo. Ostajajo pa npr. ruski černozjóm, ruska in ukrajinska dúma, poljski zlót, češki háček, hrvaški sábor, makedonsko sobránje ipd.

3.7. Za konec še beseda o primernosti izrazov tujka in izposojenka. Izraza sta primerna že zato, ker sta enobesedna in lahko predstavljata poenobesedenje ne samo zvez tuja beseda oz. izposojena beseda, ampak tudi tuja oz. izposojena besedna zve$z a$. Dober slovar tujk mora namreč vsebovati tudi ustaljene tuje besedne zveze, kot so piece touchée, a cappella, fast food, ki jim $\mathrm{z}$ ločeno pisavo celo $\mathrm{v}$ slovenščini priznavamo večbesednost. Izraza pa sta primerna tudi zato, ker sta ustaljena. Zveza slovar tujk že zaradi Verbinca na Slovenskem nekaj pomeni, pri izrazu izposojenka pa nas tudi ne sme preveč motiti dobesedno razumevanje, še zlasti zato ne, ker nekatere izposojenke vendarle tudi vrnemo, kot je to v primeru híša. To besedo, ki smo si jo izposodili iz stvnem. $h \bar{u} s$, smo vrnili bavarskim Nemcem, ki imajo iz naše izposojenke svojo Kaise, od tod pa smo si mi spet izposodili našo kájžo.

Prispelo avgusta 2004, sprejeto decembra 2004

Received August 2004, accepted December 2004

\section{Literatura}

Breznik, A. 1906. O tujkah in izposojenkah. Dom in svet 18: 149-54. Ljubljana. Ponatisnjeno v: A. Breznik, Jezikoslovne razprave. (Izbral in uredil J. Toporišič). Ljubljana 1982. Str. 365-70.

plast teh posebnosti pa so tudi nemške in druge ljudske izposojenke. Ob koncu 19. stoletja je bil torej fájmošter bolj slovenski (vendar manj slovanski) od žúpnika in žájfa bolj slovenska (in manj slovanska) od míla. Slovensko šolstvo je žal z dobrim namenom, narediti slovenščino bolj slovansko, poleg mnogih izposojenk zatrlo tudi marsikaj pristno slovenskega. Mene so npr. v šoli učili, da dežuje, da dež kvečjemu pada (tako priporoča tudi SSKJ). Če sem rekel ali napisal, da dež gre (po SSKJ je to pogovorno), so me popravili, pa vendar je to od omenjenih možnosti edina pristno slovenska. Po Pleteršniku dež po slovensko lahko samo gre (enako je npr. v ruščini), v starejšem jeziku, pri Vodniku, je dežz celo hodil. Glagol deževati je umetna tvorjenka, narejena iz dež, kakor je nem. regnen 'deževati' narejeno iz Regen 'dež', po šolsko pa silimo dež padati, tako kot pada hrvaška kiša.

${ }^{8}$ Brez večjega uspeha se je takim novotarijam upiral že Škrabec 1905: 1, ki je nasprotoval uvedbi češkega kôleka $\mathrm{v}$ škodo ljudskemu štémplju. Breznik, n. m., ki je tako stališče razširil tudi na domače neologizme, se sprašuje o smiselnosti zamenjave ljudske izposojenke cúker z umetno tvorjenko sládkor, ki je narejena iz prvega dela pridevnika sládek in drugega dela izposojenke cúkor. 
Snoj, M. 1997. Slovenski etimološki slovar. Ljubljana.

SSKJ. Slovar slovenskega knjižnega jezika. Ljubljana 1970-91.

Škrabec, S. 1905. O učenju naše knjižne slovenščine v začetnih in višjih učiliščih. (Dalje.). Cvetje z vertov sv. Frančiška XXII/1. Gorica. Ponatisnjeno v: S. Škrabec, Jezikoslovna dela III. Ur. Jože Toporišič. Nova Gorica 1995. Str. 104.

Toporišǐc, J. 1992. Enciklopedija slovenskega jezika. Ljubljana.

Toporišič, J. 2000. Slovenska slovnica. Četrta, prenovljena in razširjena izdaja. Maribor.

Veliki slovar tujk. Urednik-redaktor M. Tavzes. Ljubljana 2002.

Verbinc, F. 1968. Slovar tujk. Ljubljana.

Walde, A., Hofmann, J. B. 1938-56. Lateinisches etymologisches Wörterbuch. Zweite, umgearbeitete Auflage. Heidelberg.

\section{O prevzetih besedah, tujkah in izposojenkah}

Članek obravnava vprašanje nadaljnje delitve slovenskih besed tujega izvora. Avtor soglaša z Breznikom, ki prevzete besede deli na izposojenka in tujke. Definiciji obeh terminov prilagodi spoznanjem in potrebam našega časa. Izposojenka je $\mathrm{v}$ članku definirana kot beseda (ali besedna zveza), ki jo je preprosto ljudstvo vpeljalo iz sosednjega narečja tujega jezika v svoje narečje, tujka pa kot prevzeta beseda (ali besedna zveza), ki jo je v slovenski knjižni jezik iz tujega knjižnega jezika vpeljal izobraženec. Izposojenka je torej ljudska, tujka pa knjižna prevzeta beseda. Izhodiščna pozicija izposojenke je govorjeni jezik, praviloma narečje, izhodiščna pozicija tujke pa napisani, praviloma knjižni, pogosto strokovni jezik.

Pri prevzemu izposojenke lahko računamo s štirimi vrstami prilagoditev. 1. Če tujejezična predloga vsebuje slovenščini tuj glas ali glasovno skupino, se ta v slovenščini zamenja s slovenskim približkom, npr. bákla iz srvnem. vackel. 2. Beseda se prilagodi slovenskemu morfološkemu sistemu, npr. frájla iz bav. nem. Frailein. 3. Beseda se spremeni iz drugih, večinoma težko opredeljivih razlogov, najverjetneje po pomoti, ker pač niso motivirane, npr. marajón prek majarón iz furl. majaron. 4. Marsikatera sprememba je v slovenččini le navidezna, saj ne smemo izhajati iz sosednjega knjižnega jezika, temveč iz narečja: pávola ni iz nem. Baumwolle, temveč iz narečne avstrijskobavarske besede pa(um)wolle 'bombaž', ki ustreza nemški knjižni Baumwolle Pri prevzemu tujke lahko računamo le s prilagoditvami, ki so tu navedene pod točkama 1. in 2. Razmejevanje problematičnih primerov je stvar eksaktne etimološke obravnave, $v$ prvi vrsti filološke analize.

Praktična stran problema je vprašanje, kaj spada $\mathrm{v}$ dober slovar tujk. Ta mora $\mathrm{v}$ principu vsebovati vse slovenske besede in besedne zveze, ki so jih slovenski izobraženci od 16. stol. dalje vpeljali v slovenski knjižni jezik neposredno iz tujih knjižnih jezikov, npr. cédra, džéz, in sicer ne glede na to, kako se pišejo, džéz ali jazz. Poleg tega mora vsebovati tudi tiste priponske tvorjenke, ki se dejansko uporabljajo, npr. cedrovína, džézovski, džezístka. Predponske tvorjenke tipa prediskutírati, razformírati naj ne bi sodile $\mathrm{v}$ splošni slovar tujk, temveč kvečjemu $\mathrm{v}$ omejenem obsegu v šolsko različico. Enako velja za sestavljenke tipa nèkonvencionálen, prótitánkovski. Pač pa bi hibridne zloženke tipa delohólik eventualno lahko našle prostor 
tudi $\mathrm{v}$ splošnem slovarju tujk. Slengovske izposojenke tipa džánki, pisano tudi junky/junkie, ne spadajo $\mathrm{v}$ slovar tujk, ker je sleng po zvrsti bližje narečju kot knjižnemu jeziku. Slovar tujk naj tudi ne bi obravnaval tistih, iz drugih slovanskih jezikov prevzetih besed, ki so se v poldrugem stoletju šolske vzgoje tako udomačile, da jih ne občutimo več kot tuje, npr. žúpnik, plín, načín.

\section{Loans, Foreignisms and Borrowings}

The article deals with the classification of words of foreign origin. In agreement with Breznik, the author divides loanwords into borrowings and foreignisms, adjusting the definitions to present-day needs and state of knowledge. A borrowing (izposojenka) is defined in the paper as a word (or collocation) that lay people have introduced into their own dialect from a neighboring dialect; a foreignism (tujka) is a loanword (or loan-collocation) that an educated person has introduced into Standard Slovene from another standard language. It follows that a borrowing is a lay loanword and a foreignism is a standard loanword. The point of departure for a borrowing is the spoken language, as a rule a dialect; the point of departure for a foreignism is written language, as a rule standard, and usually the language of a profession.

In the process of assimilating borrowings there are four types of adjustment. 1. If the foreign word contains a sound or group of sounds that is not native to Slovene, the closest Slovene sound(s) is/are substituted for it/them, e.g., bákla 'torch' from Middle High German vackel. 2. The loanword assimilates to the Slovene morphological system, e.g., frájla 'young lady (expr.)' from Bavarian German Frailein. 3. The word changes due to other, difficult-to-determine reasons, probably by mistake, as they are not motivated, e.g., marajón 'marjoram' via majarón from Friulian majaron. 4. Many changes in Slovene are only apparent, since the standard language is considered rather than the proper dialect source, e.g., pávola 'cotton thread', which is not from German Baumwolle, but from Austrian Bavarian pa(um)wolle 'cotton', corresponding to German standard Baumwolle. As to foreignisms only changes 1 . and 2. come into play. The delineation of problematic examples is the domain of precise etymological study, first and foremost of philological analysis.

The practical side of the problem concerns what material goes into a good Slovene dictionary of foreignisms. In principle, it should include all Slovene words and collocations that Slovene intellectuals have imported directly from foreign languages into the standard language since the sixteenth century, e.g., cédra 'cedar', and, moreover, regardless of how they are written, e.g., džéz or jazz 'jazz'. In addition it must include those suffixed derivatives that are actually used, e.g., cedroví$n a$ 'cedar wood', džézovski 'pertaining to jazz', džezístka 'jazz musician (fem.)'. Prefixed derivatives of the type prediskutirati 'to debate something', razformírati 'to disband something' do not belong in a general dictionary of foreignisms; at most they should be included to a limited degree in a scholastic handbook. The same holds for compounds of the type nèkonvencionálen 'unconventional', prótitánkovski 'anti-tank (adj.)'. However, hybrid compounds like delohólik 'workaholic' might be appropriately included in a general dictionary of foreignisms. Slang loans such as džánki, written also junky/junkie 'narcotics addict', do not belong in a dictionary of 
foreignisms, since slang is closer to dialect than standard language. A Slovene dictionary of foreignisms should not treat borrowings from other Slavic languages that have, in the last century and a half of elementary education, become so assimilated that they are no longer felt to be foreign, e.g., žúpnik 'parish priest', plín 'gas', način 'manner, way'. 